\title{
6000-YEAR CLIMATE RECORDS IN AN ICE CORE FROM THE HØGHETTA ICE DOME IN NORTHERN SPITSBERGEN
}

\author{
by \\ Y. Fujii, \\ (National Institute of Polar Research, Kaga 1-9-10, Itabashi-ku, Tokyo 173, Japan) \\ K. Kamiyama, \\ (Geophysical Research Station, Kyoto University, Beppu 874, Japan)
}

T. Kawamura, T. Kameda,

(Institute of Low Temperature Science, Hokkaido University, Kita 19 Nishi 8, Sapporo 060, Japan)

K. Izumi,

(Research Institute for Hazards in Snowy Areas, Niigata University, Igarashi, Niigata 950-21, Japan)

K. Satow,

(Nagaoka College of Technology, Nagaoka 940, Japan)

H. Enomoto,

(Kitami Institute of Technology, Kitami 090, Japan)

T. Nakamura,

(Radioisotope Center, Nagoya University, Chikusa-ku, Nagoya 464, Japan)

J.O. Hagen,

(Norwegian Polar Research Institute, Postboks 158, 1330 Oslo, Norway)

Y. Gjessing,

(Department of Geophysics, University of Bergen, N-5007 Bergen, Norway)

and

O. Watanabe

(National Institute of Polar Research, Kaga 1-9-10, Itabashi-ku, Tokyo 173, Japan)

\section{ABSTRACT}

In 1987 an ice core to the bedrock at a depth of $85.6 \mathrm{~m}$ was drilled at the top of Høghetta ice dome in northern Spitsbergen. Chronology of the ice core was examined by tritium and ${ }^{14} \mathrm{C}$ methods showing time gap at about $50 \mathrm{~m}$ depth. The age of three bottom ice samples was determined as $4150-5670$ year B.P. by ${ }^{14} \mathrm{C}$ method done for frozen bacteria colonies and a frozen petal. This chronology and negative bottom temperature of $-9.4^{\circ} \mathrm{C}$ suggest that glaciers in Spitsbergen shrank considerably during the hypsithermal. The $\mathrm{pH}$ of melt-water samples lower than 5.0 corresponds well to large northern hemispheric volcanic eruptions during the last 300 years. Increase of acidity from $30 \mathrm{~m}$ depth to the surface may reflect the spread of air pollution to the Arctic during the past 200 years. On the basis of ice-core analyses on electrical conductivity, $\mathrm{pH}$, chemical composition and air bubble pattern, climate and environment in Spitsbergen during the last 6000 years are discussed.

\section{INTRODUCTION}

A recent global circulation model (GCM) indicates large-amplitude climatic variation in the marginal zone of the Arctic cryosphere because of the positive feedback effect of the extent of sea ice and snow cover on climate (Manabe and Stauffer, 1980). As Spitsbergen in the Arctic is located in the seasonal sea-ice zone, glaciers there are expected to preserve palaeoclimatic variation well. A Soviet glaciological team has been conducting a long-term ice-core drilling program in southern and central Spitsperger and

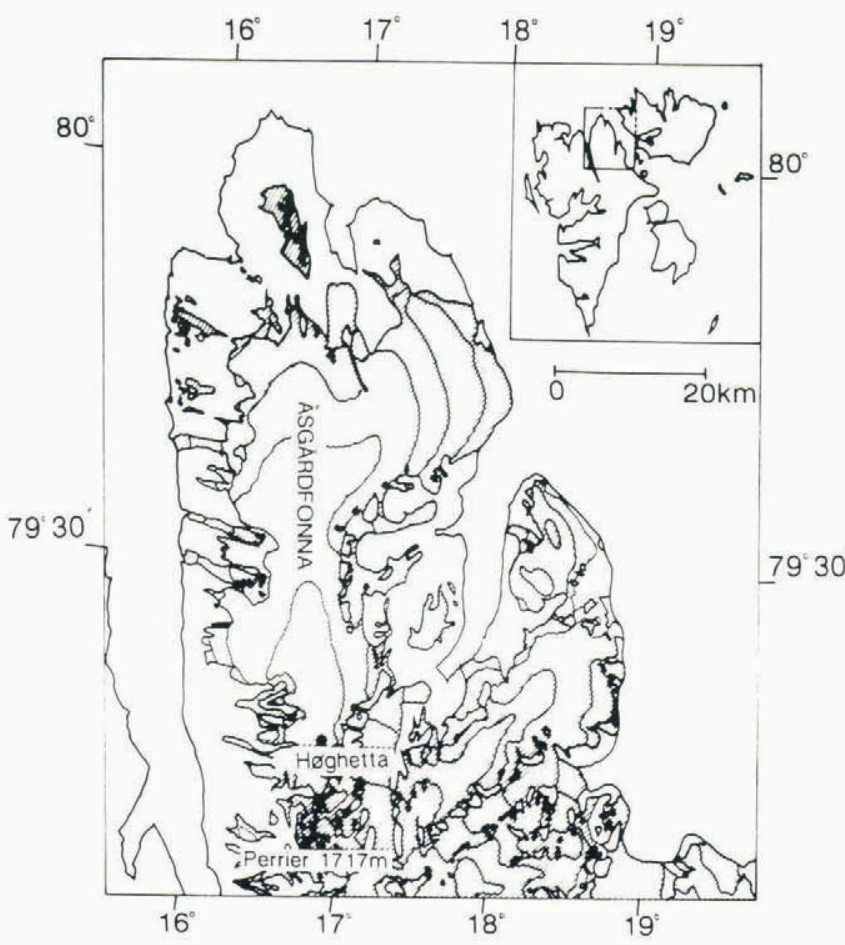

Fig. 1. Location of ice core drilling site shown by solid circle at Høghetta ice dome in northern Spitsbergen. 


$\begin{array}{lllll}\text { Age Depth } & \text { Electrical Conductivity } & \text { SH } & \text { Sand Particle } & \text { Bacteria Clear Ice }\end{array}$
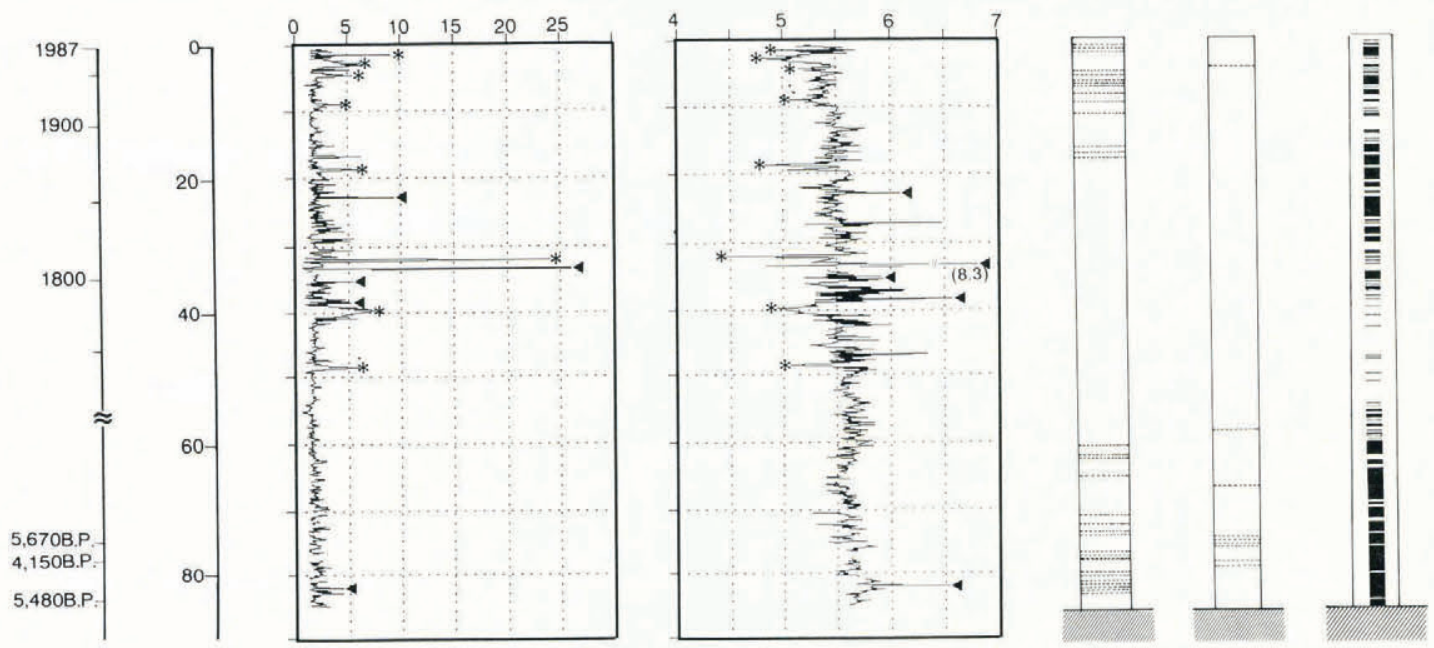

Fig. 2. Profiles of electrical conductivity, $\mathrm{pH}$, layers with visible sand particles and bacteria colonies, with a suggested time scale. Asterisks and solid triangles, respectively, mark signals of electrical conductivity and $\mathrm{pH}$ corresponding to volcanic events and terrestrial salt-rich layers.

Nordaustlandet, Svalbard (Zagorodnov, 1988). However, no ice-core drilling has been done before in northern Spitsbergen where the firn line is located at the highest elevation in Svalbard (personal communication from Liestol) probably due to lower precipitation and development of superimposed ice.

We therefore planned ice-core drilling in northern Spitsbergen for the study of the palaeoclimate-environment system during the last thousand years.

\section{FIELD WORK}

Ice-core drilling was carried out at the top of an ice dome called Høghetta in northern Spitsbergen $\left(16^{\circ} 50^{\prime} \mathrm{E}\right.$, $79^{\circ} 17^{\prime} \mathrm{N}, 1200 \mathrm{~m}$ a.s.1.; Fig. 1) with an electro-mechanical drill by the Japanese Arctic Glaciological Expedition (JAGE) from May to June 1987, as outlined by Watanabe and Fujii (1988).

Drilling reached a very hard layer at $85.61 \mathrm{~m}$ depth. Judging from the following evidence, the hard layer is thought to be bedrock: the drill could not penetrate further, blades of the drill were blunted, and small fragments of rock were collected in the grease oil applied to the cable head which was winched down to the hard surface.

Ice-core analyses in situ were carried out on the following items: stratigraphy, electrical conductivity, $\mathrm{pH}$ density, ice fabrics, grain size, air bubble shape and total gas content. Some ice core and melt-water samples were transported to Japan and stored in a low-temperature room
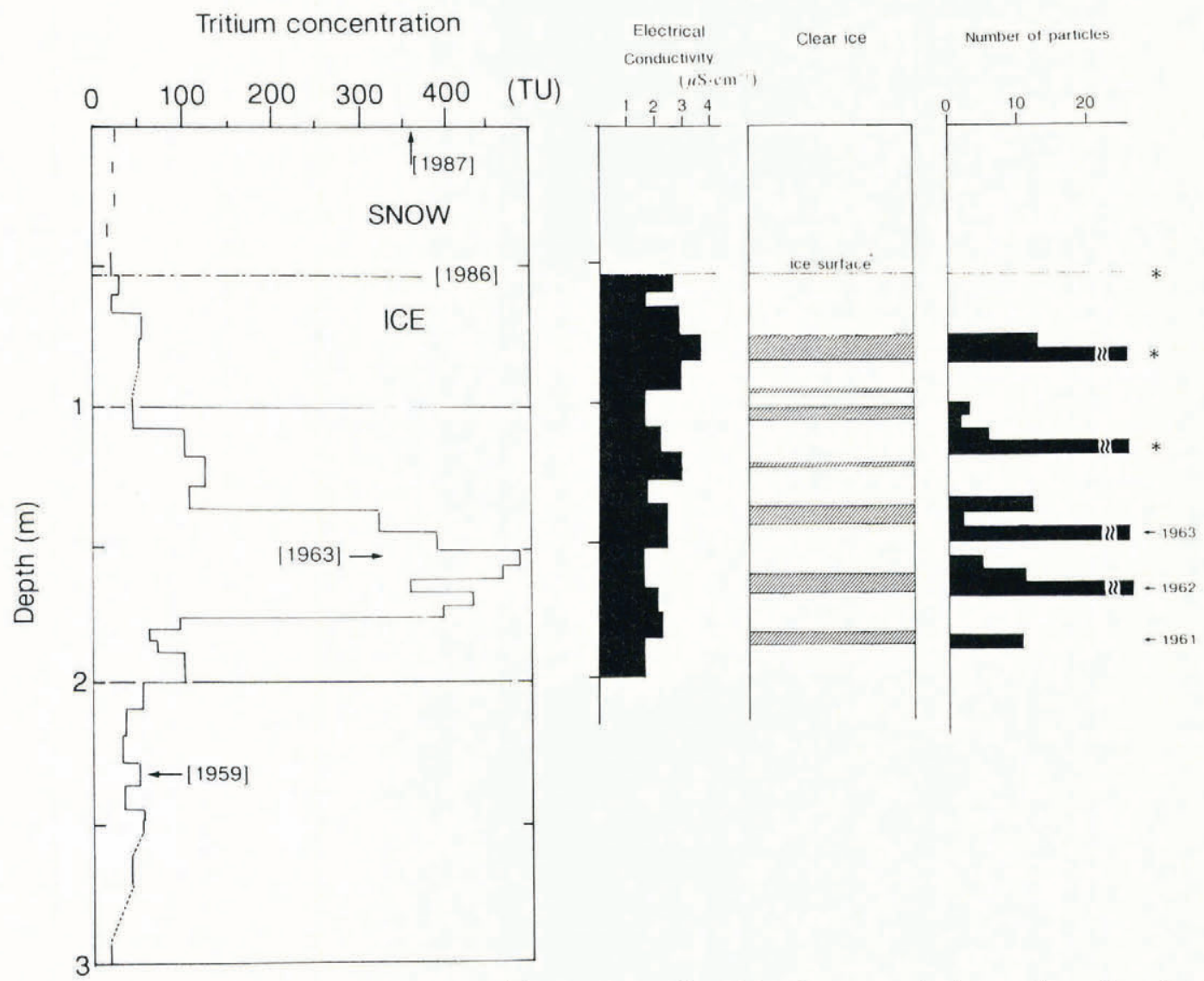

Fig. 3. Tritium content, electrical conductivity and stratigraphic features of the surface $3 \mathrm{~m}$ layer Estimated years are shown in the figure. Asterisks indicate probable annual layer boundaries. 
of the National Institute of Polar Research for the following analyses: chemical composition, tritium content, ${ }^{210} \mathrm{~Pb},{ }^{14} \mathrm{C}$, oxygen isotope ratio and others.

\section{RESULTS AND DISCUSSION}

The results of analyses for the whole core are shown in Figure 2, with a suggested time scale. Interpretation of the results is discussed below.

\section{Core chronology}

Tritium content and some surface stratigraphic features for the surface $3 \mathrm{~m}$ layer are shown in Figure 3. The top $0.54 \mathrm{~m}$ is snow deposited in winter 1986/87 and the layer below $0.54 \mathrm{~m}$ is superimposed ice, some with air bubbles. A significant peak at $1.6 \mathrm{~m}$ is thought to be the 1963 level, and a minor peak at 1.95 or $2.3 \mathrm{~m}$ depths below it indicates the 1959 horizon. According to the tritium profile at Dye-3, Greenland (Koide and others, 1982), a minimum in 1960 and 1961 from the moratorium on atmospheric nuclear tests was followed by a rapid increase from 1962. On the analogy of the tritium profile at Dye-3, the pre-moratorium peak in 1959 should be the peak at $2.3 \mathrm{~m}$ depth. This gives an average accumulation rate of about $20 \mathrm{~cm}$ of ice for the period between 1959 and 1963 .

The periodic cycle of $20 \mathrm{~cm}$ is partly recognized in visible sand particle numbers, electrical conductivity and intervals of clear ice layers as shown in Figure 3. Furthermore, cobwebbed air bubbles develop with a thickness of about $20 \mathrm{~cm}$ below the ice surface at $0.54 \mathrm{~m}$ depth. The periodicity of $20 \mathrm{~cm}$ is therefore thought to be the predominant accumulation rate, though the mean rate is $4.7 \mathrm{~cm}$ of ice for the period from 1963 to 1986 (from tritium peak to ice surface), probably due to negative mass balance in some years during this period. The $20 \mathrm{~cm}$ ice is used for estimation of ice-core age before 1963 in this paper.

Judging from significant signals with both low $\mathrm{pH}$ and high electrical conductivity, major volcanic events are marked with asterisks in Figure 2. The ages of volcanic signals estimated with the above-mentioned accumulation rate correspond to volcanic events as shown in Table I.

Present chronology seems to be reasonable because the strong and prolonged acid signal at $39.7 \mathrm{~m}$ depth corresponds to the volcanic eruption of Laki in 1783, which caused the highest acid fallout since 1500 A.D. in the acidity record of ice cores from Greenland (Hammer and others, 1980).

${ }^{14} \mathrm{C}$ dating was adapted for small bacteria colonies found in ice core samples at $75.3 \mathrm{~m}$ and $85.2 \mathrm{~m}$ depths and for a petal frozen at $78.8 \mathrm{~m}$ depth, using the Tandetron Accelerator Mass Spectrometer at Nagoya University. We obtained the following results which indicate that the bottom ice has the age of 4150-5670 year B.P., generally considered to be hypsithermal. Age inversion with respect to the depositional sequence is found but the reason is not clear.
NUTA-670 $75.3 \mathrm{~m}$ depth
$\begin{array}{ll}\text { NUTA-671 } & 78.8 \mathrm{~m} \text { depth } \\ \text { NUTA-698 } & 85.2 \mathrm{~m} \text { depth }\end{array}$
$5670 \pm 100$ year B.P. (bacteria)
$4150 \pm 290$ year B.P. (petal)
$5480 \pm 400$ year B.P. (bacteria)

TABLE I. DEPTHS, ESTIMATED AGES AND VOLCANIC EVENTS

Depth

Estimated age

Corresponding volcanic events

\section{pH profile}

In-situ measurement of $\mathrm{pH}$ was carried out continuously with a $\mathrm{pH}$ meter (HM-30S, TOA Electrics Ltd) for melt-water of ice samples cut into $10-20 \mathrm{~cm}$ intervals. Kamiyama and others (1989) divided the $\mathrm{pH}$ profile shown in Figure 2 into three fractions: the upper from the surface to about $20 \mathrm{~m}$ depth, the middle from about $20 \mathrm{~m}$ to about $50 \mathrm{~m}$ depth, and the lower from about $50 \mathrm{~m}$ depth to the base of the glacier. Variation of $\mathrm{pH}$ decreases below about $50 \mathrm{~m}$ depth, suggesting a time gap at this depth. These fractions are associated with climatic and environmental difference as discussed below.

The increase of acidity from about $30 \mathrm{~m}$ depth to the surface is clear in Figure 4, probably due to increase in acidity of precipitation in this region since the industrial revolution. The pollutant is presumed to be transported from civilized middle latitudes as indicated by measurements of $\mathrm{SO}_{4}^{2-}$ at $\mathrm{Ny}$ Ålesund in Spitsbergen (Iversen and Joranger, 1985).

\section{Electrical conductivity}

Electrical conductivity of melt-water was measured insitu with a meter (CM-1K, TOA Electrics Ltd) fitted with a sensor for low conductivity (CV-1001SC, TOA Electrics Ltd). The profile of electrical conductivity (Kamiyama and others, 1989) is shown in Figure 2. The peaks exceed $5 \mu \mathrm{S} \mathrm{cm}^{-1}$ concentrate between 17 and $48 \mathrm{~m}$ depths and are well correlated with both low and high pH events.

Peaks of high electrical conductivity at low $\mathrm{pH}$ shown with an asterisk in Figure 2 correspond to great volcanic eruptions, as mentioned above. On the other hand, peaks with high electrical conductivity and high $\mathrm{pH}$, shown with solid triangles, probably contain terrestrial salts; a high content of $\mathrm{Ca}$ occurs in samples at the peaks. Particularly high electrical conductivities of $24 \mu \mathrm{S} \mathrm{cm}^{-1}$ at $30 \mathrm{~m}$ depth and $26 \mu \mathrm{S} \mathrm{cm}^{-1}$ at $32 \mathrm{~m}$ depth correspond to minimum and maximum $\mathrm{pH}$. These suggest the frequent mass transportation of impurities to this region around 1800 A.D.

\section{Sand particles}

Sand particles were seen in clear ice from the surface to $20 \mathrm{~m}$ depth, and below $60 \mathrm{~m}$ depth to the glacier bed, as

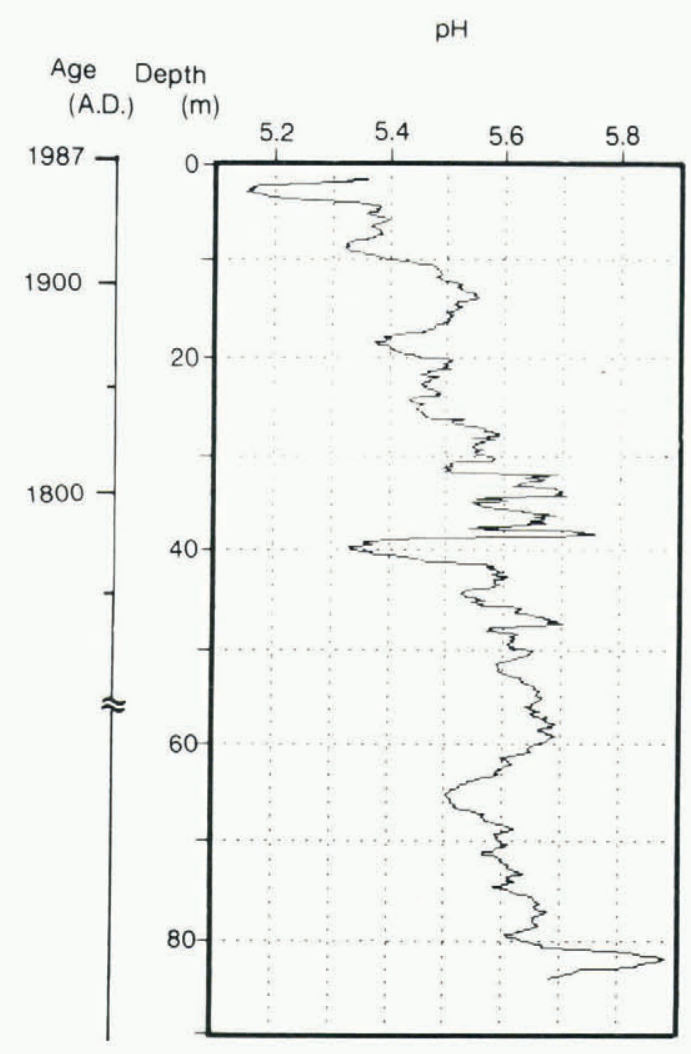

Fig. 4. Smoothed variation (20-point running mean) of $\mathrm{pH}$ of melt-water core samples, indicating increase of acidity since about 1800 A.D. 


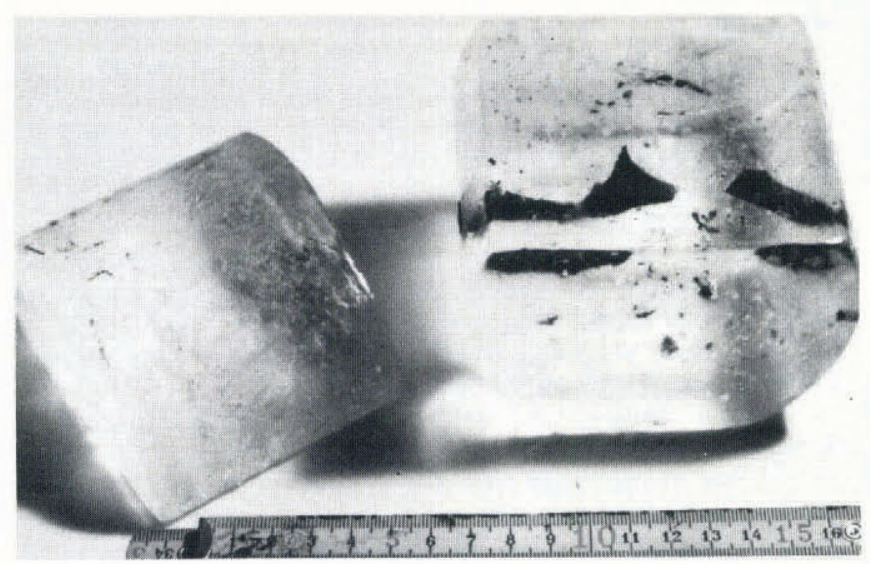

Fig. 5. Largest bacteria colony found frozen at $75.3 \mathrm{~m}$ depth. The ${ }^{14} \mathrm{C}$ age is $5670 \pm 100$ year B.P., during the hypsithermal.

shown on the left of Figure 2. As the particles are larger than $0.2-0.5 \mathrm{~mm}$ in diameter, they are thought to have been transported only short distances, from a local source.

This suggests that the environment during the hypsithermal and the period from 1880 A.D. to the present included: (1) a larger extent of snow-free area near the glacier, and/or (2) prevailing southerly winds where snow-free areas are located today.

\section{Visible organic matter}

Bacteria colonies were observed in ice at $4.9 \mathrm{~m}$ depth and frequently below $58.7 \mathrm{~m}$ depth to the glacier bed, as shown on the right of Figure 2; diameters range from a few $\mathrm{mm}$ to about $1 \mathrm{~cm}$ (Fig. 5). As these bacteria colonies grow in melt-water pools on glaciers, not in ice (Kohshima, 1989), supra-glacial ponds seem to have developed about 100 year B.P. and during the hypsithermal.

A petal $7 \times 6 \mathrm{~mm}$ in size, frozen in at $74.8 \mathrm{~m}$ depth, had a ${ }^{14} \mathrm{C}$ age of $4150 \pm 290$ B.P. Existence of these organic substances suggests that it was warm, and therefore that the glacier was considerably thinner, during the hypsithermal.

\section{Air bubble shape}

Shapes and distribution of air bubbles were observed through the entire core and classified into five patterns (Kameda and others, 1989). Their distribution probably depends on climate, which affected the formation of air bubbles. Bubble-free clear ice, probably formed by freezing of a supra-glacial pond, was predominant below $60 \mathrm{~m}$ depth to the glacier bed, as shown in Figure 2. This formation of bubble-free ice corresponds to the warm climate during the hypsithermal. Bubble-free clear ice was rarely observed between 30 and $60 \mathrm{~m}$ depths. This suggests colder summers and/or higher snow accumulation during the period corresponding to those depths.
Bubble-layer type, which reflects the previous snow stratification, may have been formed by freezing of saturated snow with melt-water. This kind of air bubble developed between 5 and $15 \mathrm{~m}$ depths and 30 and $50 \mathrm{~m}$ depths.

\section{Estimated palaeoclimate during the last 6000 years}

The results obtained by ice-core analyses mentioned above are summarized in Table II. Estimated climatic conditions are outlined at the right of the table.

Very warm climate lasted from about 6000 B.P. to 4000 B.P. at least in northern Spitsbergen, judging from the existence of bacteria colonies and a petal frozen in ice below $60 \mathrm{~m}$ in depth, with the above-mentioned ${ }^{14} \mathrm{C}$ ages. As temperature at the bottom of the borehole is $-9.4 \mathrm{C}$, subglacial melting is not likely to have occurred even during the hypsithermal. Thickness of ice at the top of the present ice dome is, therefore, thought to have been only $35 \mathrm{~m}$, about one-third of the present thickness, during the hypsithermal.

After the hypsithermal, there seems to have been a time gap between about 4000 B.P. and 1700 A.D., probably due to negative mass balance of the glacier before about 1700 A.D. Climatic conditions during 1700 to 1880 A.D. in the Little Ice Age seem to have been cold and stormy. Absence of visual sand particles and organic material indicates long seasons of snow cover with no supra-glacial pond formation during the period. A less negative stable oxygen isotope ratio is shown in an ice core from Lomonsovfonna in central Spitsbergen during this period (Vaykmyae and others, 1985). The large variability of both $\mathrm{pH}$ and electrical conductivity during this period suggests stormy weather.

The period from 1880 to 1945 A.D. is characterized by a fluctuating warm-cold climate. After 1945 A.D., the climate has become warmer and a bit stormy.

\section{CONCLUSION}

The present study shows the possibility of reconstructing past climates and environments by analysing an ice core from a superimposed ice zone on an existing Arctic glacier. Further studies on stable oxygen isotope ratio, chemical composition including organic matter, and ${ }^{210} \mathrm{~Pb}$ dating, would clarify and add detail to climate and environment during the last 6000 years.

\section{ACKNOWLEDGEMENTS}

We express our sincere gratitude to Drs J.A. Holtet, O. Orheim, Y. Ohta, and Messrs T. Siggerud and Kunut of the Norsk Polarinstitutt for their cooperation in our field work. Our particular thanks are due to Professor S. Kobayashi of Niigata University, the chairman of the Arctic Research Committee of the Japanese Society of Snow and Ice, for his help in organizing the project. This research was supported financially by a grant-in-aid for overseas scientific research of the Japanese Ministry of Education, Culture and Science.

TABLE II. SUMMARY OF RESULTS OBTAINED BY ANALYSES OF AN ICE CORE FROM HØGHETTA, AND ESTIMATED CLIMATIC CONDITIONS DURING THE LAST 6000 YEARS.

\begin{tabular}{ccccccccc} 
Depth & Period & \multicolumn{2}{c}{ Variability } & Sand & Organic matter & Clear ice & Bubble layer & Estimated climate \\
m & \multicolumn{9}{c}{ pH } & EC & & & & \\
$0-5$ & $1945-$ present & L & L & Y & Y & Y & N & warm \\
$5-20$ & $1880-1945$ A.D. & S & S & Y & N & Y & Y & cold/warm \\
$20-50$ & $1770-1880$ A.D. & LL & LL & N & N & Y/N & Y & cold and stormy \\
$50-85$ & $4000-6000$ B.P. & S & S & Y & YY & YY & N & very warm
\end{tabular}




\section{REFERENCES}

Hammer, C.U., H.B. Clausen, and W. Dansgaard. 1980 Greenland ice sheet evidence of post-glacial volcanism and its climatic impact. Nature, 228(5788), 230-235.

Iversen, T. and E. Joranger. 1985. Arctic air pollution and large scale atmospheric flows. Atmos. Environ., 19(12), 2099-2108.

Kameda, T., T. Kawamura, Y. Fujii, and H. Enomoto 1989. Shapes and distribution of air bubbles in an ice core from Asgardfonna, Spitsbergen. Bull. Glacier Res., 7, 221-226.

Kamiyama, K., and 6 others. 1989. In-situ measurements of electrical conductivity and $\mathrm{pH}$ in core samples from a glacier in Spitsbergen, Svalbard. J. Glaciol., 35(120), 292-294.

Kohshima, S. 1989. Glaciological importance of microorganisms in the surface mud-like materials and dirt layer particles of the Chongce Ice Cap and Gozha Glacier,
West Kunlun Mountains, China. Bull. Glacier Res., 7, 59-65.

Koide, M., R.Michel, E.D. Goldberg, M.M. Herron and C.C. Langway, jr. 1982. Characterization of radioactive fallout from pre- and post-moratorium tests to Polar ice caps. Nature, 296(5857), 544-547.

Manabe, S. and R.J. Stouffer. 1980. Sensitivity of a global climate model to an increase of $\mathrm{CO}_{2}$ concentration in the atmosphere. J. Geophys. Res., 85(C10), 5529-5554.

Vaykmyae, R.A., T.A. Martma, Ya.-M.K. Punning, and K.R. Tyugu. 1985. Variations in $6^{18} \mathrm{O}$ and $\mathrm{Cl}^{-}$in an ice core from Vestfonna, Nordaustlandet. Polar Geogr. Geol. 9(4), 329-333.

Watanabe, O. and Y. Fujii. 1988. Outlines of the Japanese Arctic Glaciological Expedition in 1987. Bull. Glacier Res., 6, 47-50.

Zagorodnov, V.S. 1988. Recent Soviet activities on ice core drilling and core investigations in Arctic region. Bull. Glacier Res., 6, 81-84. 